\title{
An analysis of the parental age effect for inv dup (15)
}

\author{
J M CONNOR AND D H GILMORE
}

From the Duncan Guthrie Institute of Medical Genetics, Yorkhill, Glasgow G3 8SJ.

SUMMARY Parental ages and birth order were analysed in 16 sporadic cases of inv dup (15) using the method of Smith. ${ }^{1}$ A significant maternal age effect was apparent $\left(d_{m}=5.989\right.$, SE 1.86; $d_{f}=2 \cdot 02$, SE 2.496; $d_{b}=-0 \cdot 138$, SE 0.46).

Inv dup (15) is a clinically important cause of mental retardation with few or no dysmorphic features. ${ }^{2}$ The parental origin of the extra chromosomal material is not known but several authors have commented on the increased parental ages. ${ }^{3}$ We decided to analyse this parental age effect since a major contribution from one parent would be an important clue to the likely origin of the extra chromosome.

\section{Methods and results}

A survey of published reports on inv dup (15) revealed 16 cases which included maternal age, paternal age, birth order, and normal parental karyotypes. These data are presented in table 1 , which also includes the year of birth and country of origin of each patient and a numerical reference.

Received for publication 19 September 1983.

Accepted for publication 21 October 1983.

TABLE 1 Parental ages and birth order in 16 sporadic cases of inv dup (15).

\begin{tabular}{llllll}
\hline $\begin{array}{l}\text { Maternal } \\
\text { age }(y r)\end{array}$ & $\begin{array}{l}\text { Paternal } \\
\text { age }(y \boldsymbol{r})\end{array}$ & $\begin{array}{l}\text { Birth } \\
\text { order }\end{array}$ & $\begin{array}{l}\text { Origin } \\
\text { of case }\end{array}$ & $\begin{array}{l}\text { Year of } \\
\text { birth }\end{array}$ & Reference \\
\hline 30 & 31 & 3 & USA & 1964 & 4 \\
41 & 44 & 6 & Italy & 1973 & 5 \\
35 & 36 & 5 & USA & 1970 & 6 \\
39 & 40 & 1 & Japan & 1977 & 7 \\
30 & 26 & 3 & USA & 1964 & 3 \\
36 & 38 & 4 & USA & 1953 & 3 \\
38 & 38 & 3 & USA & 1962 & 3 \\
36 & 37 & 5 & Germany & 1967 & 3 \\
26 & 27 & 1 & Israel & 1974 & 8 \\
33 & 38 & 6 & UK & 1978 & 3 \\
30 & 33 & 2 & Italy & 1957 & 9 \\
36 & 48 & 3 & Italy & 1971 & 9 \\
28 & 32 & 1 & Italy & 1980 & 9 \\
29 & 40 & 1 & Italy & 1976 & 9 \\
26 & 28 & 1 & Italy & 1979 & 9 \\
30 & 44 & 3 & UK & 1980 & 2 \\
& & & & & \\
Mean & Mean & Mean & & & \\
$32 \cdot 7$ & $36 \cdot 3$ & 3 & & & \\
SD & SD & SD & & & \\
$4 \cdot 69$ & $6 \cdot 38$ & $1 \cdot 79$ & & & \\
\hline
\end{tabular}

TABLE 2 Control population data.

\begin{tabular}{lrll}
\hline & Mean & $S D$ & Reference \\
\hline Parental ages and birth order & $25 \cdot 79$ & & \\
Maternal age & $28 \cdot 58$ & $5 \cdot 1$ & 10 \\
Paternal age & $1 \cdot 95$ & $6 \cdot 13$ & 10 \\
Birth order & $1 \cdot 16$ & 10 \\
& & \\
Parental age and birth order correlations & & \\
Maternal age and paternal age $\left(\mathrm{r}_{\mathrm{mb}}\right)$ & $0 \cdot 72$ & 11 \\
Paternal age and birth order $\left(\mathrm{r}_{\mathrm{fb}}\right)$ & $0 \cdot 3$ & 12 \\
Maternal age and birth order $\left(\mathrm{r}_{\mathrm{mb}}\right)$ & 0.45 & 11 \\
\hline
\end{tabular}

The choice of control data presents a problem in view of the diverse countries of origin of these patients. Data from England and Wales were chosen as complete figures for average paternal age, maternal age, and birth order, and correlations of these three variables are available (table 2). The year 1973 was chosen as this was the median year of birth of the patients.

Mean maternal age, paternal age, and birth order were all raised in comparison with these control data. Analysis by the method of Smith ${ }^{1}$ revealed a direct maternal age effect $\left(d_{m}\right)$ of 5.989 (2 SE 3.72), a direct paternal age effect $\left(d_{f}\right)$ of 2.02 (2 SE 4.992), and a direct birth order effect $\left(d_{b}\right)$ of -0.138 (2 SE 0.4222). The direct maternal age effect exceeds thrice its standard error and thus is highly statistically significant. Neither the direct paternal age effect nor the direct birth order effect exceed twice their standard errors.

\section{Discussion}

Older mothers tend to be married to older fathers and tend to have more children than younger mothers. Thus an analysis of raised parental ages needs to determine the relative contribution of these three components: paternal age, maternal age, and birth order. Analysis by the method of Smith ${ }^{1}$ uses multiple linear regression to provide values for the direct effect of each of these variables. It also 
provides a standard error for each and if any of the direct estimates exceeds twice their standard error then they are statistically significant. In the present study a significant direct effect was apparent only for maternal age.

In all such studies the choice of appropriate control data is important as parental ages and birth order are liable to change with time in various ethnic groups. Generally data are used for the mean or median year of birth of the patients. This was possible in the present study, but the choice of ethnic group was more difficult since the patients had diverse countries of origin. Control data from England and Wales were chosen as these were both complete and readily available. With this limitation, the presence of such a strong direct maternal age effect suggests, as in trisomy 21 , that the mother is the usual source of the extra chromosome in inv dup (15). This proposition could be studied further by the use of restriction fragment length polymorphisms in the involved region of chromosome 15.

We wish to thank Action Research for the Crippled Child for their continued support.

\section{References}

1 Smith CAB. Note on the estimation of parental age effects. Ann Hum Genet 1972;35:337-42.

2 Gilmore DH, Boyd E, McClure JP, Batstone P, Connor JM. Inv dup (15) with mental retardation but few dysmorphic features. J Med Genet 1984;21:221-3.
3 Wisniewski L, Hassold T, Heffelfinger J, Higginds JV, Cytogenetic and clinical studies in five cases of inv dup (15). Hum Genet 1979;50:259-70.

4 Howard PN, Stoddard GR, Yarbrough KM. Partial trisomy D and Giemsa banding. Am J Hum Genet $1974 ; 26: 41$ A.

5 Furbetta M, Rosi G, Biagioni M, Cossu P, Cao A. A case of extra small acrocentric bisatellited chromosome in a non-mongoloid child. Humangenetik 1975;30:259-63.

6 Mankinen CB, Holt JG, Sears JW. Partial trisomy 15 in a young girl. Clin Genet 1976;10:27-32.

7 Fujita H, Sakamoto Y, Hamamoto Y. An extra idic (15p) (q11) chromosome in Prader-Willi syndrome. Hum Genet $1980 ; 55: 409-11$.

8 Cohen MM, Rosenmann A, Dagan J, Legum C. Partial trisomy D: a diagnostic and cytogenetic dilemma. $J$ Med Genet 1976;13:535-8.

9 Zannoti M, Preto A, Giovanardi PR, Dallapicolla B. i Extra dicentric pter leads to q21/22 chromosomes in iv five unrelated patients with a distinctive syndrome of $\vec{\omega}$ progressive psychomotor retardation, seizures, hyper 음 reactivity and dermatoglyphic abnormalities. J Ment Defic Res 1980;4:235-42.

10 Registrar General. Statistical review of England and Wales for the year 1973. Part 2. London: HMSO, 1975.

11 Emery AEH. Methodology in medical genetics. An introduction to statistical methods. Edinburgh, London, New York: Churchill Livingstone, 1976.

12 Blank CE. Apert's syndrome (a type of acrocephalosyndactyly): observations on a British series of thirtynine cases. Ann Hum Genet 1960;24:151-64.

Correspondence and requests for reprints to $\mathrm{Dr}$ J M Connor, Department of Medical Genetics, Duncan Guthrie Institute of Medical Genetics, Yorkhill, Glasgow G3 8SJ. 